\title{
Decentralization as an Institutional System, Prospects and Retrospect: Case of Four Weredas of Tigrai
}

\author{
Sintayoh Fissha \\ College of Business and Economics, MacEwan Univesity, Edmonton (AB), Canada
}

Meheret Berhanu

College of Business and Economics, Mekelle University, Mekelle, Ethiopia

Received: Feb. 17, 2018 Accepted: Mar. 26, 2018 Online published: Jun. 13, 2018

doi:10.5296/jpag.v8i2.13279 URL: https://doi.org/10.5296/jpag.v8i2.13279

\begin{abstract}
Following the demise of the Derg regime in 1991, the most important reform agenda of Ethiopia was to restructure the country and its civil administration along ethnic lines, and to establish ethnicity as the defining principle of political, social and economic discourse. Consequently the country's political map was redrawn along ethnic lines, which gave way to "Regional states". The regional states secured administrative and legislative power within a federal framework. . Success stories of decentralization encouraged policy makers to launch fiscal decentralization which extended the regions' planning and resource allocation powers to each district (wereda)level. This apparently enabled them to improve service expansion and development.
\end{abstract}

Despite this general perception this study seeks to critically review the impacts of decentralization (both fiscal and administrative) on districts considering four weredas of Tigrai regional state (northern part of Ethiopia). To conduct this study both primary and secondary data sources was and analyzed using simple descriptive, and statistical method of analysis. Results obtained based on the three variables (measures effect of decentralization on community participation good governance, and minimizing revenue expenditure gap) reveals positive progress. Indeed, there are promising changes related to administrative matters and of community participation in designing and implementation of development plans. These changes also are enhanced individuals' participation in productivity, which expedited poverty reduction as well, as indicated by the growing improvements in local livelihoods. However, the gains of decentralization on governance and minimizing revenue expenditure gap are far from satisfactory. As long as the real participation of locals and problems of local capacity remains at stake but is still suffered more from resource limitations. This study recommends 
some adjustments with the decentralization approach, and appropriate implementation modalities so as to solve the procedural and skill related problems, and to minimize misuse of resource in a way that assists to be more effectively. ${ }^{l}$

\section{Decentralization as a Context}

\subsection{Introduction}

Since the 1980 's, centralization system is losing ground while transferring part of the power of the central government to regional or local authorities become a common political formula (practice) around the globe. Consequently, several countries established national commissions to assess the advantages of decentralization while many more others made decentralization or fiscal federalism as the centerpiece of their political agendas (campaign) without making detailed investigations on its effects. The meanings of decentralization differ from scholars to scholars; it embraces varieties of concepts, which must be carefully analyzed in any particular country before determining that national projects should be geared towards to the reorganization of financial, administrative, or services delivery system (World Bank, 2003). The more widely accepted definition of 'decentralization' entails the sharing of central government powers with other institutions, especially those geographically separated or responsible for specific functions, or those given jurisdiction over specific physical locations (Ndegwa, 2002; Turner and Mulme, 1997).

Based on this definition the notion of 'decentralization' shares two common functions. The first function is territorial where authority power and responsibility are transferred down to lower levels in territorial hierarchy while the second function concerns about how authority and responsibility are transferred to lower agencies that are functionally specialized and are often imported ideas.

Because in most developing countries decentralization was introduced due to the pressures posed by international financial institutions on African national governments to reform centralized political systems and economic planning. Directly or indirectly all these institutions influenced many of the African economic system, adopt economic measures such as market liberalization, state decentralization, and move towards political pluralism (Stohr, 2001). If we consider the view of the government officials of Ethiopia the situation sounds somewhat different even though is subject to different criticisms. According to the head of the Tigray region institutional policy officer and head of each study woredas decentralization was introduced not only because of imposition from different international institutions but was also considering the political and development advantage of the nation and/or the region.

According to them imposition from international organizations was not the sole reason that forced Ethiopia to go through profound economic and political changes (J. Spielman, J. Cohen, and Tewodaj, 2006). Some government officials deem that the success stories they

'Acknowledgements: I thank Mekelle University, and the Belgian Government for financing this study. It was one of the MU-IUC project research topic undertaken in Tigray regional state (Northern part of Ethiopia). 
had when the current government were guerrilla fighters is the case that pushed them to favor decentralization policy. In pre 1990s, when TPLF, one of the parties of Ethiopian People Revolutionary Democratic Front (EPRDF) was administering the rural part of Ethiopia they have noticed the impact of implementing informal decentralization administration system. Seems the move towards decentralization in Ethiopia is part of an unfolding process in that country that goes to the heart of its political economy and sounds as if inborn than imported type.

\subsection{Statement of the Problem}

In most developing countries in general and of Ethiopia in particular the issue of institution building has gained space. It is now generally recognized that 'institutions matter' and that the associated incentive structures substantially influence economic performance (Bardhan and Udry, 1999). Even though which institution affects economic progress and how is too complex, institutional failure impedes development.

The term 'institution' is so vague, for the purposes of this paper it simply refers to the change in structural frameworks and administrative system. Considering several cases of institutional changes in Ethiopia, decentralization is taken as one among many others. The decentralization drive in Ethiopia in is due to diverse reason and development in the European Union was one of these factors (Tanzi, 1995).

Decentralization in Ethiopia went through two phases. The first wave of decentralization occurred in the period 1991-2000, and the second wave refers to the decade; since 2001 on ward which is often named as District Level Decentralization Program (DLDP). In adopting decentralization policy, the government focused on creating and empowering National/Regional Governments geared towards the reduction of poverty and of inequality. Building a decentralized structure was expected to bring changes related public service delivery, foster democratization, and to strengthen national integration (Steinich, 2002).

Many of the recent studies and reports (MOFED, 2010; MOFED 2012), suggests that poverty has been considerably reduced after implementing decentralization. On the other hand, there are different criticisms pertinent to the links between poverty and inequality, which shows an increasing trend (MOFED 2010) $)^{2}$, Related to this the Country Governance Profile assessment shows about the institutional failure, compliance with formal rules and regulations in the Ethiopian civil service is high and control system is strong (ADB \& ADF, 2009). Even a previous study conducted by Yigremew, Nega, and Haregewoin (2005) indicates this; poverty has grown much deeper and wider in Ethiopia over the recent years, which implies failure of expectations.

The strategic plan of the country over the last decades focuses on improving the country's economic and institutional development; as priority policy issues designed to bring about meaningful changes in the lives of the poor (marginalized). Nevertheless, failure to

${ }^{2}$ The inequality as measured by the Gini Coefficient, shows a moderate rise at national level while sharply rising in urban areas. 
implement these pertinent policies appropriately produced much unexpected results which made poverty to be still pervasive. Of all, good governance and vibrant civil society are among the priority issues identified in the framework of its "Right to the Heard Program" (Ibid).

Since decentralization was intended to create a better system related to administration, and resource use it was also expected to motivate officials to design programs from a more cross sectoral perspectives that could led to achievement of economic advantage. However, unlike these stated goals, there is an extended argument and continuous debate that emerged from dubious procedures of overall implementation, where the availability of skilled manpower is very limited and the miss use of resources is high (Tegenge and Kassahun, 2007; and Meheret, 2007).

A study on decentralization and its effect in Ethiopia (based on experience of different regions) also supports the stated argument. They argued: achievements were far lower than expectations as the smallest administrative units' hardly exercised degree of political power granted by the EFEDRE Constitution. In relation to this different writers (Tegegne and Kassahun 2007, and Dom and Mussa, 2006 ) argued stating:

While the first wave of decentralization (administrative decentralization) has registered significant achievements in local governance and regional self-rule, it was not capable of bringing genuine self rule particularly at lower level of administration where governance and decentralization matter most. Thus, our main argument is the above finding needs to be justified, empirical information on implementation of decentralization policy in Ethiopia and particularly in the study woredas is so complex, or is largely missing and this study is expected to fill that gap.

Therefore, this study tried to investigate the effects of decentralization in Tigrai region, and examined the specific achievements and its challenges.3 The fundamental question was whether the ongoing decentralization helped to achieve the needed development or not. The impact of devolution on a gamut of fundamental institutional issues, such as the level of corruption would be scrutinized.

It seeks to investigate whether findings by previous authors are consistent with the Tegrayan experiences or not. With this in mind, this study seeks to answer the following questions:

- To what extent does decentralization empower small administrative units?

- What are the opportunities and challenges of implementing fiscal and administrative decentralization?

\subsection{Objective}

The main objective of this study is to investigate the effect of decentralization in improving

\footnotetext{
${ }^{3}$ Tigrai is one of the regional state in the northern part of Ethiopia. The researchers were very much interested on identifying decentralization and its specific relevance to poverty reduction of the rural areas, which mainly falls within the Giba catchment
} 


\section{Macrothink}

livelihood of the rural communities often attained as a result of having better institutional performances taking the case of four weredas of Tigrai (Keleteawelaelo, Atsebi, Tankuabergele, and Hagereselam), northern part of Ethiopia. The specific objectives are:

- To examine the progresses attained related to administration implementation system after the launching of decentralization in Tigrai region.

- To compare and contrast the implication of fiscal and administrative decentralization in Tigrai, investigate the easiness to implement as per expected in enhancing participation and good governance.

\subsection{Hypothesis}

By applying the methodology, which is discussed below this study has tried to verify or nullify the following.

$\mathrm{H}_{0}$ : Decentralization led to the improvement of the administrative performance of small administrative unit.

$\mathrm{H}_{1}$ : Decentralization did not have much effect either on the locals' participation and good governance.

\subsection{Instruments and Methodology of the Study}

\subsubsection{Methodologies}

To conduct this study both, primary and secondary data sources have been used. Primary data was collected through both, focus group discussion and distributing questionnaire to a sample of randomly and purposively selected respondents in two rounds in 2010 and in 2011. Moreover, the secondary data was obtained from reviewing different related studies (annual reports of the region and the concerned woredas').

\subsubsection{The Study Area}

The study was conducted in Tigrai (Northern part of Ethiopia). Specifically in the four Tegrayan weredas of -Kelteawelaelo (Weinadega), Atsebi (Dega), Tankuabergele (Kola), and Hagereselam (Dega), and specific location of the woreds' is located in the figure blow ( the line blocked by the arrow). 


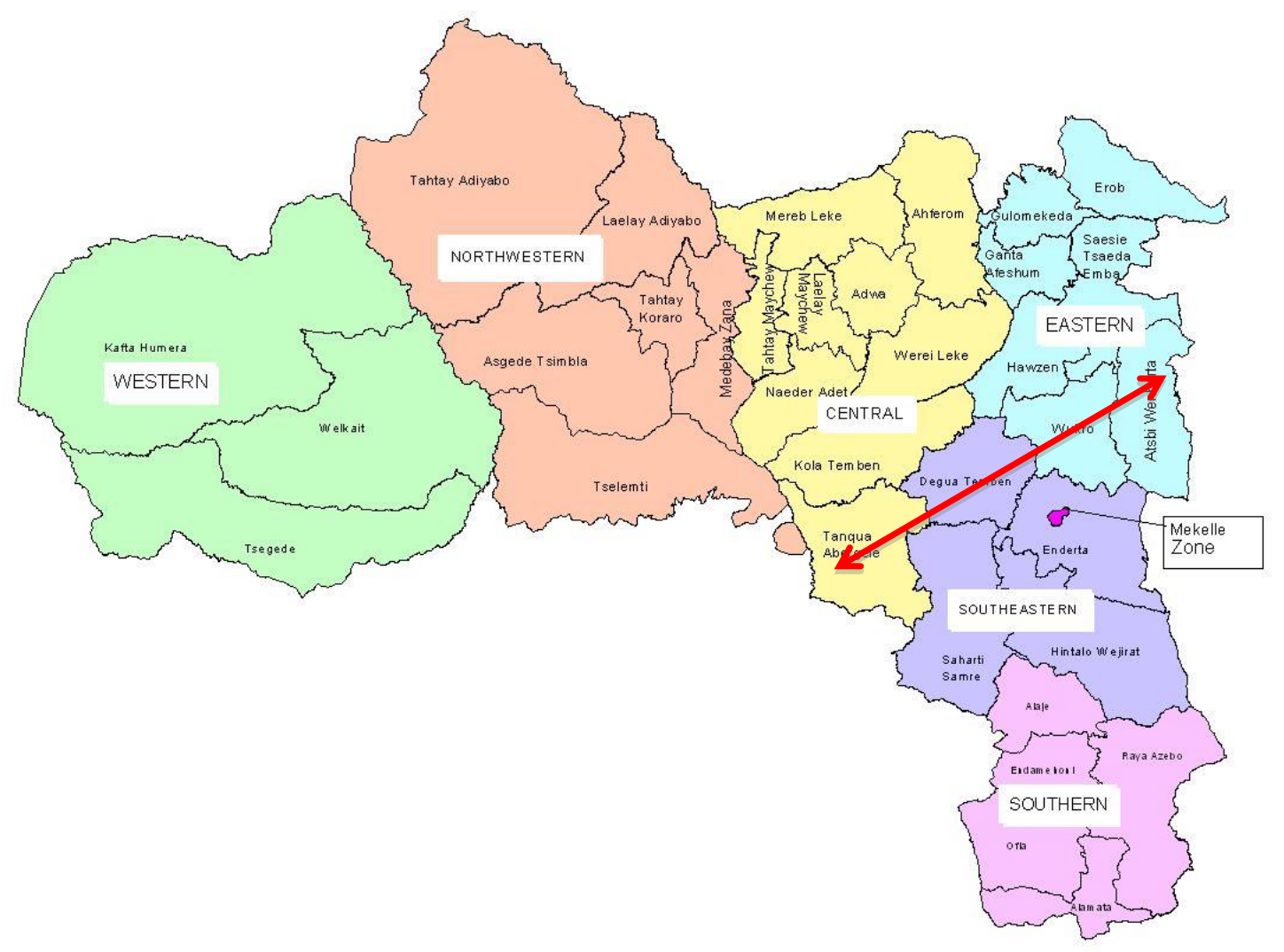

Tigray is located in the northern part of Ethiopia. In Tigray ,there are six zonal administration regions: the Southern ,the Central, the Eastern, the Western, the North Western, and one urban zone; the regional capital, Mekelle. The region comprises of a total of 46 Woredas (districts), 12 urban weredas and 660 Tabias (sub-districts).

Tirgay covers an area of approximately $54,572 \mathrm{sq} \mathrm{km}$, and has a total population of $4,314,456$; out of which 49.2 and 50.8 are females and males, respectively. About $80.5 \%$ of the population lives in rural areas (census of 1999 E.C), while another $19.5 \%$ are urban residents. The altitude of the region varies from about 500 meters above sea level (masl) in the north-east to almost 4000 (masl) in the north-west and about 4000 masl in the south-west. The agro-ecology of the region is broadly categorized into lowland (Kola- less than 150 masl), medium highland (Weinadega - 1500 to 2300 masl), and upper highland (Dega -2300 to 3000 ). About $53 \%$ of the region is lowland, $39 \%$ medium highland, and $8 \%$ upper highland (BoFED 2006).

This study is specifically conducted in the four Tegrayan weredas of -Kelteawelaelo (Weinadega), Atsebi (Dega), Tankuabergele (Kola), and Hagereselam (Dega) - here after will be denoted as the "study weredas. Selection of the study areas was based on different criteria's. First, these localities are within the spheres of Giba catchment (basin), where MU-IUC project ${ }^{4}$ is operating, and the study should be only within these boundaries. The

${ }^{4} \mathrm{MU}-\mathrm{IUC}$ is Belgium sponsored project based in Mekelle Univeristy mainly involving in 
second selection criterion was based on ecological or geographical basis. Accordingly, Kilteawelaelo, Hagereselam, Atsebi, and Tankuaabergele were chosen.

\subsubsection{Data Collection}

One rationale of collecting data through survey is to obtain a specific answer to the research questions. In order to conduct this study initially (in 2010) a total number of 200 samples were randomly collected from each weredas. However, data collected using questionnaire distribution has been enriched through FGD, a total of 8 FGD was made with the population of the weredas (two FGD from each).

The selection of equal sample size from the four-study area was done purposely. In selecting the desired samples form four of the weredas multistage random sampling technique was used. Hence, sampling of the subjects started from preparing the list of Tabias ${ }^{5}$ in each weredas. At the third stage all the households from the selected wereda were listed and sample sizes of 50 from each stratum (kushet) were taken using simple random sampling technique.

In the second round survey (2011) another 200 sample were collected from these four woredas using simple random and purposive sampling approach. The sample was proportionally distributed to 100 communities and 100 administrators in four wereda.

\subsubsection{Data Analysis}

The collected information was analyzed using two methods of analysis, simple descriptive statistics such as percentage, table, ratio, and statistical method (MANOVA). MANOVA is a statistical technique designed by (R.A Fisher, 1925). ${ }^{6}$ For a simple one-way MANOVA, the data set should have one independent variable (grouping variable) and at least two dependent variables. If the model is a type in which it is assumed that two factor determines the mean value of a variable it is called two-factor analysis of variance, two ways MANOVA (Chatfield, 1995). ANOVA tests for differences among group means, and assumes that the mean of a variable depends on only one factor, namely the sample from which the observation is taken. But, MANOVA tests for differences among the multivariate effects on the inference based on the resulting linear model.

In both cases (One way MANOVA and two way MANOVA) it is assumed that the data are normally distributed with the same variance, $\sigma^{2}$. The analysis of variance approach for testing a null hypothesis $\left(\mathrm{H}_{0}\right)$ concerning multiple parameters is based on driving two

development and capacity building development programs

${ }^{5}$ Tabia is smallest administrative unit, which is the same as to sub-district

${ }^{6}$ ANOVA was developed by R.A. Fisher in the mid of 1920s', and become widely known after being included in Fisher's 1925 book Statistical Methods for Research Works, cited in Efron, B. 1998, Journal of Statistical Science, Vol. 13, No. 2. 
estimator of the common variance, $\sigma^{2}$. The first estimator is valid estimator of $\sigma^{2}$ whether the null hypothesis is true or not, while the second one is a valid estimator only when $\mathrm{H}_{0}$ is true.

In addition when $\mathrm{H}_{0}$ is not true, this latter estimator will over estimate $\mathrm{H}_{0}$, in that estimator will tend to exceed. Since the two estimators should be close to each other when $\mathrm{H}_{0}$ is true, where as the second estimator should tend to be larger than the first. When $\mathrm{H}_{0}$ is not true, it is natural to reject $\mathrm{H}_{0}$ when the second estimator is significantly larger than the first. In this study since the dependent and independent variable are more than two, two-way MANOVA (the model has more than two dependant and independent variables) was used.

These two independent variable (place and code) are generated as a result of categorizing respondents based on space and responsibility. Space refers to the area of resident (wereda); since the targeted wereda are not having the same access and agro ecological zone, the researchers deem this could have different impact in implementing decentralization. Similarly, the interviewed individuals have different status (administrative position, which was coded as 1 , and representatives of the community coded as zero), and it is believed that these two categories are supposed to have the same reply about the effect of decentralization if decentralization outcomes is as expected. If not it is an indication of variance, which could be effect of differences in level of satisfaction.

Given these categorization in this study MANOVA is preferred to multiple ANOVAs (or regressions with dummy variables) because:

- Multiple ANOVA/OLS depends on chance. For example, if you have 20 dependent variables, you expect $\mathrm{X}$ to have a "significant" effect on one of them if $\alpha=0.05$. MANOVA does a global test of whether group means differ for any of the variables.

- ANOVA/OLS ignore the inter-correlations between the independent variables (IVs) as MANOVA takes them into account, it can provide a more powerful statistical test. MANOVA uses more information about the data than ANOVA does.

Another common use of MANOVA is in a repeated measures design, where the same variable is measured at different points in time (J. Faraway, 2002). MANOVA used instead of a series of one-at-a-time ANOVA for two main reasons. First, if you follow up a significant multivariate test with a bunch of ANOVAs on the individual variables without adjusting the error rates for the individual tests, there's no "protection". The second reason to do MANOVA is ANOVAs may produce a significant main effect on the dependent variable (DV), but in combination they might suggests that the variables are more meaningful taken together than considered separately.

\section{Review of Related Studies}

\subsection{Related Theoretical and Empirical Reviews}

"Decentralization" generally means the devolution of decision-making powers (MartinezVazques, 2011). Countries exercise decentralization processes for different reasons. Some do 
it in the quest for a more efficient and cleaner public sector, while others are disenchanted with the performance of planning and centralized policies (e.g., socialist economies).

The other reason could be political opportunism (Ibid) like using decentralization for electoral objectives and/or just a desire to not be left behind in this popular form of institutional reform. Given these controversies it is widely recognized that over recent years one can see worldwide interest in decentralization. In most developing countries decentralization being a recent event and often politically motivated was treated as if it would result in an efficient allocation of public resources (LDI, 2013). In Ethiopia regionalization and other strong constitutional guarantees for all of the nations (ethnicities) were enshrined into Constitution in 1995. The essence was similar to decentralization and was established after the down fall of the Derg regime. Since then political officials and policy makers argued stating: decentralization has been explicitly launched to enhance community participation in local decision-making, community empowerment, and increase local governments' responsiveness and accountability. Decentralization stands a much better chance of reaching the poor (Hertogs, 1999). Consequently efficiency and reducing of economic inequalities among the states was expected to emerge. ${ }^{7}$

Although this is the general expectation of this reform (decentralization system), the debate on the subject still continues to invite controversy. Proponents considered decentralization as a panacea for adjusting the institutional system, reforming civil service, improving service and other utility deliveries ((Shah, 2002 and 2006); (Abay et al., 2004); and B. Elhiraika (2007)),

However, there are studies that show the "winners" of the decentralization process has been the autonomous communities than the lower corporations (Juan C., 2001). Other research also indicates how small administrative units are benefiting as a result of implementing decentralization policy like collection of more revenues. Jimenez and C.Smith (2005) provided a clue related to the advantages of shifts from a matching grant to a block-funding grant through the flypaper effect, and its implication on rising revenue and improving of public service delivery. In this study a 1 per cent increase in decentralization was associated with approximately 4 per cent reduction in infant mortality.

On the other hand decentralization studies conducted in Ethiopia and else where also shows the limitations executing decentralization (Meheret, 2007; Tesfay, 2006; LID, 2013). Based on the study conducted in Ethiopia Meheret specifically argues stating: "over the past couple of years... the process of pushing down authority, responsibility and resources to wereda has not been successfully carried out" (Mheret, 2007:96).

Both theoretical and empirical analyses discussed tend to be inconclusive and come up with ambiguous and differing results. Empirical study related to the country (Ethiopia) or the study region is not much. Based on what has been discussed above one can conclude that this is the outcome of the theoretical trade-off, which reflects the various pros and cons of a decentralized government structure. But we shall also consider that direct empirical 
estimations are still scarce and do not sufficiently involve new results of economic growth theory and empiricism. In addition, conducting further study on the topic will also help to give more information about the topic, and can serve policy makers and planners.

\section{Data Analysis and Discussions}

\subsection{Decentralization and Locals Participation}

Immediately, after its seizure of government power, the Ethiopian People's Revolutionary Democratic Front (EPRDF) organized a national conference to create the charter that asserted the right of nationalities to self-determination up to secession. This has opened the door for the creation of local and regional councils along ethnic lines. The next paragraph presents how this regionalization or formally known as decentralization has contributed to the improvement of public administration, governance, and rising revenue of the state in the way that enhances economic development.

The form of the federal government is defined based on Articles 45 - 49 of the Ethiopian constitution, the government is made up of ethnically based regional state; administration structure of the country was revamped into (9) regional states and two special administration cities (Addis Ababa and Dire Dawa). The regional states were also further divided into 66 zones comprising 556 weredas. The regional states are: Tigray; Afar; Amhara; Oromo; Benshanguel-Gumuz; Somali; Southern Nations Nationalities and peoples (SNNP); Gambella Peoples; Harari Peoples; and Welayeta People. Moreover, within the state, people have the right to create their own decision provided that it is within the will and approval of the regional state (Getachew and Fraser, 2001).

Decentralization at regional and woreda level is firmly established through foundational provisions in the Federal Constitution, giving Regional States the power to establish "other administrative levels that they find necessary." (Art 50(4)). It is on the basis of this article all regions, and specifically the study region (Tigrai) implemented decentralization (administrative decentralization, which was introduced from 1991, and $\mathrm{t}$ fiscal decentralization launched in 2001).

The second decentralization introduced to empower small administrative regions about their development needs and resource allocations. Though these are the general principles of both decentralization there are arguments on its actual effect, while some acknowledged about its consequence that its up to the expected, the other groups are with criticism of decentralization and they argued that its just mere of ideology stated on paper with nothing impact on development. Woredas don't have full mandate and power either about their administrative decision and/or resource allocation. Therefore, this study has tried to examine its impact posing some important questions and is discussed below.

Demographic character of the respondents shows that of the total number of respondents $50 \%$ were administrators and $50 \%$ were from the community. Of these proportional sampled groups $31.5 \%$ were female and 68.5 were male. All these were with the age range $70.8 \%$ productive, and the rest were dependent population (higher than age 65 years). 
While the data collected individuals were asked about the administrative system practiced since decentralization launched. Most of them replied that they are familiar about both, centralized (they referred Derg system) and decentralized system. They appreciated the second stating: it encouraged individuals to reflect their view, motivate them to participate in different development activities, and granted alternatives. Both, communities and administrators (99\%) had positive perception about the system. They said introduction of decentralization in general and fiscal decentralization in particular enhanced service delivery, which led to a slight change in economic status, increasing of income. In all the study woredas informants confirmed about their mandate, acknowledged the changes, and appreciated the over all progresses obtained. But, they also did not hide their reservation on its implementation procedure that it is still locally top-down. Locals participation in implementation of development plans has progressively increased especially after the introduction of Integrated Community Based Participatory Development Planning (ICBPDP, introduced in 2009), but still ideas and orders come from the top, not from the bottom. Informants said: sometimes there are also development plans we demanded but never accepted."

Likewise administrative were asked to express what they feel regarding the effect decentralization. They appreciate the institutional change made in woreda administration; (94.5\%) said regional government is making strenuous efforts to strengthen wereda and tabia generic (i.e. non sector specific) planning capacities. They said since the inception of this system training on strategic planning has been provided, and the strategic framework of designing plan and implementing procedure is also drafted. They strongly believed that this had $\mathrm{s}$ assisted to get an insight regarding the process of developing wereda strategic plans, and implementations. However, unlike what is stated from the discussion conducted, and document analysis made researchers learned that little consideration was given to the problems in weredas that needs serious attention but not within the ambit of the regional strategic framework. This confirms most of the development plans are coming from the region than born in local. The mandate of the locals is a matter of identifying the priori need given the core plan which often comes from the nation (region), and the allocation process refers to efficient allocation of resource given the budget from the region.

Respondents were also asked about the differences between fiscal and administrative decentralization system. Almost all said while administrative decentralization is mere of political fiscal decentralization has encouraged grass roots participation in implementing local development plans and allocation of its budget thereby checking the potential strengths and constraints, a progress observed after DLDP launched.

In fact, DLDP was expected to bring all sectors and other bureaus of the wereda in one domain, facilitating closer integration of community, all sectors, and bureaus of the wereda. Nevertheless, unlike what is prescribed in the document sectors are not integrated well. In most documents it was noticed that development programs are often overlapped and sectors seem to compute more on the ownership than contributing to the development needs of the locals. This effect to less integration of development plans, opened rooms for resource miss-utilization and increasing of wastage. But, from the interviews and FGD conducted with 
the communities and head of the administrators of the woredas researchers noticed that despite these limitations this system has relatively enhanced administrative efficiency, improved community participation in planning and development, and enabled communities to owe their development program and share its $\operatorname{cost}^{8}$. This implies that unlike administrative decentralization fiscal decentralization had created an incentive for people to discuss on economic affairs and about the local governments performance, which is more relevant to them.

Regarding implementation process when these two (fiscal and administrative) are compared the satisfaction of most (70\%) informants on the procedure of implementing administrative decentralization was higher. Related to fiscal decentralization respondents appreciate the initiative but they also raised some problems. Some (43.5\%) if not most resented the burdens of continuous meeting and free labor services that they often rendered whenever schools or health centers are constructed through the orders of executives (administrators). This discloses how grass root communities and their associations lack sufficient awareness with regard to the on-going decentralization drives while prospects for entrenching accountability of service providers remains low, which is similar to the study made by (Tegegne and Kassahun, 2007).

In addition to the above, to examine the specific impacts of decentralization on institutional progress of rural, several but specific questions that believed can capture the relationship between dependent and independent variables have been forwarded. Respondents answer was analyzed using a simple statistical technique called MANOVA as illuminated in the quantitative analysis presented below (Table 1).

Table 1. Summary result of the questions related to the effects of decentralization on local community participations (The number in the table refers to percentage).

\begin{tabular}{|c|c|c|c|c|c|c|}
\hline \multirow[b]{2}{*}{ No } & \multirow[b]{2}{*}{ Indicator of Participation } & & \multicolumn{4}{|c|}{ Measurements } \\
\hline & & period & $\begin{array}{l}\text { Very } \\
\text { good }\end{array}$ & Good & average & Poor \\
\hline \multirow{2}{*}{1} & \multirow{2}{*}{$\begin{array}{l}\text { Peoples participation in planning, decision making, } \\
\text { and evaluation }\end{array}$} & before & 1.05 & 13.09 & 34.03 & 51.83 \\
\hline & & After & 11.52 & 48.69 & 30.37 & 9.42 \\
\hline \multirow{2}{*}{2} & \multirow{2}{*}{$\begin{array}{l}\text { Enhancing inter-sectoral (inter-office) relationship, } \\
\text { and facilitating discussions related to development }\end{array}$} & Before & 0.52 & 15.71 & 42.93 & 40.84 \\
\hline & & after & 13.61 & 51.31 & 26.70 & 8.38 \\
\hline \multirow{2}{*}{3} & \multirow{2}{*}{$\begin{array}{l}\text { Strengthening wereda- region coordination and } \\
\text { networking }\end{array}$} & before & 2.62 & 13.09 & 27.23 & 56.54 \\
\hline & & after & 8.36 & 53.40 & 27.75 & 10.47 \\
\hline \multirow{2}{*}{4} & \multirow{2}{*}{$\begin{array}{l}\text { Enhancing top-bottom versus bottom-top } \\
\text { relationships }\end{array}$} & Before & 2,62 & 20.94 & 30.37 & 46.0 \\
\hline & & After & 11,52 & 37.70 & 35.60 & 15.18 \\
\hline
\end{tabular}

Sources: own computed from collected data

Analysis result of Table1 indicates the effects of decentralization on locals participation,

${ }^{8}$ Almost all discussants stated: "decentralization helped to avoid delays and dependency, grants power to administer and to owe the development activities" (June-august 2010). Unlike the past, local administrative units are becoming the decision maker of their own development progress is their main justification for the above answer. 
which was made by comparing the respondents reply after decentralization with that of before. Comparison of respondents reply was made using the level of their satisfaction (measured by the scale), which was measured using Likert Scale.

Likert Scale. is often used to get an overall measurement of a particular topic (opinion or experience) and it also helps to collect specific data on contributing factors. This method was used to identify the level of dis/satisfaction of the respondents about the institutional changes (decentralization). The term good, very good, average and poor are valued as 4, 3, 2, and 1 which is similar to the words of strongly agree, agree, moderately agree and disagree. Considering all questions given in the table above, and comparison of respondents satisfaction in after with that of before clearly shows the positive impacts of the measures undertaken related to decentralization. From their response this is confirmed by the gaining of more percentage of votes of good (agree) and reduction of percentage of votes of poor (disagree). ${ }^{9}$

Therefore, based on both, qualitative and quantitative analysis made it can be said that decentralization, created an incentive for people and civic society organizations to discuss about the local governments that are relevant to them. This implies that localities are increasingly thrown onto themselves to create place for prosperity (UNCDF, 2003). Localization in this regard implies home or domestic (state) rule, which in this case is one way. In the study woredas we have learned that after decentralization administration procedures are becoming more of locally driven and owned, but not decision-making is not. This is justified by the statistical analysis presented above, decentralization effect to strengthening wereda- region coordination and networking is highest but decentralization impact in enhancing top-bottom versus bottom-top relationship still requires much effort.

Moreover, responses to each question disaggregating respondents reply into community and administrator was examined. This was made to assess whether there is a difference in perception about decentralization and its effects, which was mainly made by summing the respondents level of satisfaction. To avoid double counting researchers were careful enough and the cumulative answer was derived. This has helped to capture the effect and compare the differences of the counts obtained by each these two categories.

Table below summarizes results of the respondents (number) related to effects of decentralization on locals participation, disaggregating respondents on the basis of their position (administrator and community). The number refers to counts and captures the change in level of satisfaction within the periods (before and after decentralization) given.

\footnotetext{
${ }^{9}$ The respondents perception reveals while the percentage of good for indicators of number 1 to 4 in after have increased from 13.09 to $48.69,15.71$ to $51.3,13.09$ to 53.04 and 20.94 to 37.7 the percentage of votes for poor in after has reduced from 51.83 to $9.42,40.84$ to $8.3,56.54$ to 10.47 and 46.0 to 15.18 (for more details see Table 1).
} 
Table 2. MAOVA summary result about decentralization effect disaggregating the respondents reply

\begin{tabular}{l|l|l|l|l|l|l|l|l|l}
\hline & \multicolumn{2}{|l|}{ Administrators Response } & \multicolumn{2}{l}{ Community Response } \\
\hline & $\begin{array}{l}\text { Measurement } \\
\text { Scale base) }\end{array}$ & \multicolumn{2}{l|}{ Periods } & \multicolumn{2}{l}{$\begin{array}{l}\text { Measurement } \\
\text { (Scale base) }\end{array}$} & \multicolumn{2}{l}{ Periods } \\
\hline No & Variable & Before & After & Difference & Variable & Before & After & $\begin{array}{l}\text { Diffe } \\
\text { rence }\end{array}$ \\
\hline $\mathbf{1}$ & Very good & 24 & 123.5 & 100 & Very good & 7.5 & 66 & 58.5 \\
\hline $\mathbf{2}$ & Good & 152.9 & 423 & 270 & Good & 103.6 & 221 & 153 \\
\hline $\mathbf{3}$ & Average & 329 & 159 & -170 & Average & 145 & 173 & 28 \\
\hline $\mathbf{4}$ & Poor & 91 & 50 & -41 & Poor & 68 & 66 & 2 \\
\hline & Total & 203 & 260 & 57 & & 286 & 504 & 218 \\
\hline
\end{tabular}

Sources: own computed from the data collected

The above (Table2) result reveals that there is a positive response by both groups. It can be said decentralization creates an environment for decision makers to have up-to-date information about the preferences and problems of the local people, an effective channel for the people to express their wants and priorities, and a motivating environment for the local decision makers to respond to the local needs quickly and effectively, which is similar to the study conducted by Khaleghian (2003). Both groups perceived decentralization to have positive effect on participation, which also spur economic advantages.

Their level of responses for the scales given, very good, good, average, confirmed this and in after, which is higher than before for both groups of respondents. The level of responses by administrators for the scales of very good, good, average and poor for after was 123.5, 423, 159,50 , and 260 which is higher than before, which was given as 24, 152.9, 329, and 91 . Likewise the level of response given by the communities for the same scale in after was 66, 335,262 , and 100 is higher than before, which was given as 7.5, 103.6, 219, and 103. Second, despite the summery result shows the same effect but comparison of level of satisfaction of both these groups reveals that administrators have high level of satisfaction about the system than the second groups.

To see whether the effects of decentralization vary across places (spatial location) and in between the local communities and the officials further investigation was made by applying statistical analysis, MANOVA. As state don the methodology part since the dependent and independent variables are more than two applying MANOVA was appropriate. 
Table 3. Decentralization Effect on Locals participation computed MANOVA

Manova y1 y2 y3 y4 y5 y6 1 = code place code\#place

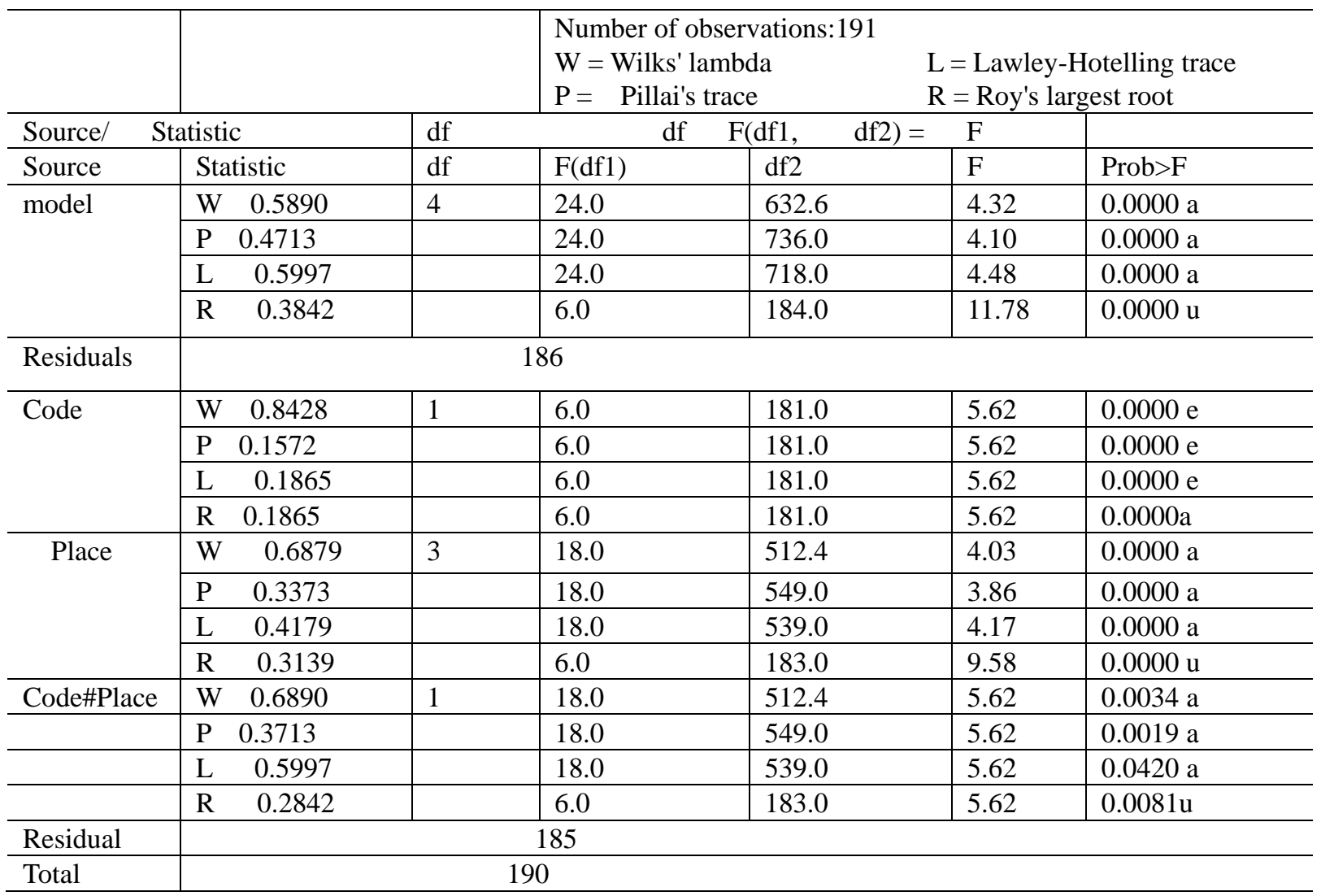

Sources: own computed from the data

The (Table3) above lists the number of observations used in the estimation. It also provides a key indicating that $\mathrm{W}$ stands for Wilks' lambda, P stands for Pillai's trace, L stands for Lawley-Hotelling trace, and R indicates Roy's largest root.

The first column of the table gives the source. Here we are testing decentralization effect (the only term in the model), and we are using residual error for the denominator of the test. Four lines of output are presented for decentralization, one line for each of the four multivariate tests, as indicated by the W, P, L, and R in the second column of the table.

The next column gives the multivariate statistics, which is indicated by the corresponding result of the letter $\mathrm{W}, \mathrm{P}, \mathrm{L}$, and $\mathrm{R}$. Some authors report $\lambda$ and other use $\theta$, given by $\theta=\lambda /(\lambda-1)$, for Roy's largest root but Stata uses $\lambda$.

The column labeled "df" gives the hypothesis degrees of freedom, the residual degrees of freedom, and the total degrees of freedom. Within the given model, there are 5 degrees of freedom, and 185 residual degrees of freedom, and 190 total degrees of freedom.

The next three columns are labeled " $\mathrm{F}(\mathrm{df} 1, \mathrm{df} 2)=\mathrm{F}$ ", and for each of the four multivariate tests. 
The degrees of freedom and F statistic are listed. The following column gives the associated p-values for the F-statistics. Since this is MANOVA two way, we consider the result of the interaction of the terms. Result for the interaction of the variables indicates that Wilks' lambda has an F statistic of 5.62 with 18 and 512.4 degrees of freedom, which produces a p-value small enough that 0.0034 is reported. The F-statistics and p-values for the other three multivariate tests follow on the three lines after Wilks' lambda.

The final column indicates whether the $\mathrm{F}$ statistic is exactly $\mathrm{F}$ distributed, is approximately $\mathrm{F}$ distributed, or is an upper bound. The letters e, a, and $\mathrm{u}$ indicate these three possibilities.

For this example, the F statistics for all the variables are approximate except the F statistic for Roy's largest root, which is an upper bound, means that the p-value is a lower bound.

The variation in perception of repsondents about the questions used to assess impact of decentralization was captured by the overall $\mathrm{F}$ test (over all three dependent variables). But in these cases the researcher most interested in is a statistic called Wilks' lambda $(\lambda)$, and the $F$ value associated with that. Lambda is a measure of the percent of variance in the DVs that is 'not explained' by differences in the level of the independent variable. Lambda varies between 1 and zero, and it is expected to be near zero (e.g, no variance that is not explained by the IV), but Lambda value indicates there is a variance.

From the result depicted in table 3 MANOVA models with more than one term, shows test results for the overall model is given by the interaction of the term code and place, followed by results for each term in $\mathrm{W}, \mathrm{P}, \mathrm{L} \& \mathrm{R}$. The interaction term, code\#place is significant at the 0.001 level. Wilks' lambda for the interaction has an exact $F$ that produces a $p$-value of 0.0034, confirms again the existence of variance about the impacts of decentralization. Even though the satisfaction obtained by both respondents in all the study woredas seems positive there is difference (variation) in their level of satisfaction, it varies from one wereda to the other werda, from people to people.

This could be due to two important reasons. First, because of their position the administrators might answer as if their highly satisfied. This seems rather speculative that the answer they respond is biased considering the implication of this investigation. Second, the variation observed in woredas (place) could be due to the economic performance (effect of ecology) and access to infrastructural facilities like road and other networking. For decentralization impact to be better or not it is mattered by skill of the implementers, the institutional system, and the location. This was noticed by the weredas considered in this study were Wekero, which is closer to Mekelle city and has access to different infrastructural facility has better performed than Tanku-abergle.

\subsection{Decentralization and Good Governance}

The next part of the analysis focuses on effects of decentralization and good governance in Tigray regional state.

Decentralization and governance are two of the political economy principles devised to improve institutional administration and if it goes as designed it can improve livelihood of the 
locals. Decentralized system is enabling to the emergence of new form of local economy if locals are main decision makers of the state economic, political, and social affairs. However, in the region where this study is conducted it is questionable whether decentralization enhanced full participation of locals in the economic, political, and social affairs, and helped to the creation of accountable and responsible leaders that minimize corruption and nepotism. The subsequent section of the paper tries to answer the question of: does decentralization enhanced proper utilization of resources to the extent that the region (Tigrai) freed out of the problems of centralized political and administrative strangle holds that perpetuated miss utilization of public resources? Although statistics on corruption are questionable, and can not be easily obtained, in the study woredas most informants blame the system saying after decentralization administrators are becoming highly corrupted not only misusing of public resource but becoming more accountable to some elites who are having money, or affiliation to them. Some study sows how corruption accounts for a significant proportion of economic activity.10 Almost in all the study wereda people complained about the dynamic shifts in their ideologyof TPLF (Tigray People Libration Front), one of the party of EPRDF that operates in the Nrothern part of Ethiopia called Tigray. They said TPLF before Derge was people centered, and any thing that comes at the expense of the society was a taboo. However, after they become government their ideology and believe is completely shifted, its more of individualism now and people don't have any space any more as its used to be.

Corruption refers to exercise of official powers against public interest or the abuse of public office for private gains. Governance is defined as the norms, traditions, and institutions by which power and authority in a country are exercised (Shah, 2004). These norms, traditions, and institutions include the institutions of participation and accountability in governance, mechanisms of citizen voice and exit, and norms and networks of civic engagement.

To see effect of decentralization on good governance in Tigray this paper adopted some of the institutional principles used in Shah. These concepts used to examine the link between decentralization (mainly judged by the indicators) and governance, which is presented in (Table4). Over all perception of the respondents related to governance was debatable, the communities expressed their (qualitative analysis) dissatisfaction, some were still appreciating it because their beneficiaries of the system. The difference in view has shown by the results of the descriptive and statistical analysis (expressed in percentage change).

${ }^{10} 2004$ World Bank study of the ramifications of corruption for service delivery concludes that an improvement of one standard deviation in the International Country Risk Guide corruption index leads to a 29 percent decrease in infant mortality rates, a 52 percent increase in satisfaction among recipients of public health care, and a 30-60 percent increase in public satisfaction. 
Table 4. Effect of Decentralization on Governance (the number in the table refers to percentage)

\begin{tabular}{|c|c|c|c|c|c|c|}
\hline & \multirow[t]{2}{*}{ Governance Indicators } & & \multicolumn{4}{|c|}{ Measurement } \\
\hline No & & Period & $\begin{array}{l}\text { Very } \\
\text { good }\end{array}$ & Good & Average & Poor \\
\hline \multirow[t]{2}{*}{1} & \multirow{2}{*}{$\begin{array}{l}\text { Does decentralization lead to improving of } \\
\text { power politics relationship; }\end{array}$} & Before & 3.14 & 27.23 .09 & 28.27 & 41.36 \\
\hline & & After & 9.95 & 35.60 & 31.41 & 32.04 \\
\hline \multirow[t]{2}{*}{2} & \multirow{2}{*}{$\begin{array}{l}\text { To what extent does decentralization increased } \\
\text { administrators' accountability to their citizen? }\end{array}$} & Before & 2.03 & 13.8 & 33.1 & 51.07 \\
\hline & & After & 5.0 & 16.8 & 33.9 & 44.3 \\
\hline \multirow[t]{2}{*}{3} & \multirow{2}{*}{$\begin{array}{l}\text { After decentralization does people have the } \\
\text { mandate of correcting their administrators? }\end{array}$} & Before & 4.2 & 9.3 & 29.4 & 57.1 \\
\hline & & After & 7.3 & 12.5 & 30.9 & 52.8 \\
\hline \multirow[t]{2}{*}{4} & \multirow{2}{*}{$\begin{array}{l}\text { Does Decentralization empower citizens to the } \\
\text { extent of demotion their administrators when } \\
\text { they found guilty }\end{array}$} & Before & 1.98 & 7.9 & 37.3 & 47.18 \\
\hline & & After & 6.31 & 9.3 & 34.21 & 49.82 \\
\hline \multirow[t]{2}{*}{5} & \multirow{2}{*}{$\begin{array}{l}\text { Does decentralization empower locals to the } \\
\text { extent of removing administrators form power } \\
\text { when they try to miss utilize public resource? }\end{array}$} & Before & 4.71 & 18.85 & 31.94 & 44.5 \\
\hline & & After & 9.42 & 36.13 & 24.08 & 30.37 \\
\hline \multirow[t]{2}{*}{6} & \multirow{2}{*}{$\begin{array}{l}\text { Does decentralization lead to the creation of } \\
\text { good governance? }\end{array}$} & Before & 1.05 & 16.32 & 34.74 & 47.89 \\
\hline & & After & 5.76 & 28.27 & 34.55 & 31.41 \\
\hline \multirow[t]{2}{*}{7} & \multirow{2}{*}{$\begin{array}{l}\text { Does decentralization effect to minimizing } \\
\text { nepotism and corruptions? }\end{array}$} & Before & 2.62 & 15.18 & 35.08 & 47.12 \\
\hline & & After & 5.24 & 27.75 & 35.0 & 31.94 \\
\hline
\end{tabular}

Source own computed from the data

Table 4 reveals the changes obtained related to governance. Effect of decentralization on governance was identified using similar approach as that of participation. The questions posed so as to examine changes on governance after introduction district level of decentralization is given in table 4 (considered as indicators). Progresses related to governance was explained by the gaining of percentage for the indicator of very good and good and reduction of percentage of gains for average and poor in after decentralization than before. Result of the descriptive analysis shows for the governance indictors of 1 and 5 there is an increasing trend of very good and good, and reduction of average and poor responses. When it is compared with pre-decentralization respondents satisfaction about its effect is better in after than before. However, for indictor number 2, 3, 4, 6 and 7 it reveal the positive change but the progress (as shown by the changes in the responses) is very little especially when its is compared with the results discussed above.

Result of the descriptive statistics is inline with some of the view of the communities forwarded during FGD, which was analyzed using content analysis. From the result it is clear that in the study woredas impact of decentralization on locals participation is better than on governance. Thus, it can be said that since the inception of DLDP, 'Tigray' (similar to any other regions) has got the autonomy of administering its area. Administrative decentralization had better effects on local community participation but proved to be little effect on governance. This has been ensured by the little reduction of responses for average and poor for all indicators given in table4, except indicator number 1 and 2 . This has also become a current source of concern among certain academic communities' and policy making circles who feared the implication of implementing such system on resource utilization and 
improving accountability is not been as it is prescribed in the manuals prepared. Instead localization has adversely affected the quality of public governance through an increase in the incidence of miss utilization of resources which is effect of lack of accountability, poor capacity and lack of technical skill, and absence of concerned citizen. In all the study woredas administrators realize the limit in their capacity, and locals also acknowledge this problem. There are individuals who claim its effect is less, this finding reflected during the discussion made with the communities, which are sometimes named as the first group. But there are also some from the interviewed (second group), praise decentralization program stating: "it helped to avoid corruption, dependency, and grants power to communities to elect and appoint their administrators." To these who praised the system it seems that unlike the past, local administrative units are becoming accountable, responsible, and committed after decentralization. Their main justification was the incidence of community participation in election, appointing of their leaders, the increasing number of women representatives in the woreda council, and the expansion of service, which can help in one way or the other. Contextually this expression is true because the political dynamism in the region shows the appointing of leaders elected by people and the increasing of women's participation in the woreda council but has several pitfalls on its procedure and at the same time it is less effective in addressing the question of the community as the first group informants stated repeatedly. Therefore, in this study the expression and perception of the first groups was sounds more as there is a wider miss utilization and allocation of resource, which is believed to be effect of increasing corruption.

Our critical argument supports the first groups who acknowledge the undergoing changes but have wider reservations on the overall framework, system design and process, and manners of implementation. They questioned the views forwarded by the second groups. These groups critically commented the entire process of decentralization in tackling corruption. Further, by drawing comparisons of governance before and after 2001, unlike the second group the first group still argue far from enhancing service expansion, decentralization is actually curtailing sustainable development because issues of corruption is becoming so complex. Based on the content analysis made their criticism (first groups) was not on the rules (system) rather it is on the technicalities of the implementation procedures as laws are miss interpreted, power politics is miss utilized, no fair justice system, and courts and judges are biased.

Like wise he process of appointing (recruiting) civil servants as a staff in different bureaus was critically criticized: Almost in all the study woredas citizens complained about the process and said "we have no clue on how one is appointed and other is fired. In most case we often see people evaluated bad are empowered to higher offices, and others who are accountable to the local needs are fired". Similarly Access to information; they said important information is accessible only to those who are very close to the decision makers". To cite a case, when there is job opportunity (vacancy), the job advertisement tends is open for a single day or two when it is supposed to be open for a week or more working days. This is intentionally made with the aim of offering the job to these who are very close or having some relationship with the employers. Its intentionally made to cheat others, because when they see that only one day is remain they may not be applied for a job believing that they 
already missed the requirements. However, the actual fact is not only because they don't fulfill the requirement but unable to meet deadline. This and other issues were areas of complied by the local people and they sound as if they have no hope about the system (informants view obtained during FGD in Tankaabergele, Atsebi, and Keleteqwelaelo; August, 2011).

Moreover, there are complaints on the delivery or disbursement of safety net program, as observed in two study woreda (Atsebi and Tanka'abergele); communities indicated how benefits provided by the public as a means of social insurance are hijacked or misappropriated. Issues related to purchase of materials through bidding was also another point highly criticized by both, communities and administrators. Related to this, the wereda administrator(s) stated ${ }^{11}$ that purchasing of office equipments and other office materials has become more complex and centralized. Due to such hectic procedures, often dominated by the regional executives the weredas could not utilize their annual budgets fully. Due to this returning unused wereda budgets or rushing to purchase goods at the end of the budget year is a common practice, leading to an increasing of wastage of public resources. In this regard, decentralization seems reversing the progresses, unless solved may increased fragmentation of political arenas. The increasing complexity of decentralized programs may raise the potential of improved delivery but it also increases the chances for misallocation of funds at different nodes of the system (Dethier, 2000).

Likewise, communities perception on evaluation (locally called gemgam) is controversial. It was surprising; almost all communities in all wereda's appreciated the pre 2001 evaluation system when TPLF was guerilla fighters. They said that in pre 2001 evaluation tradition was very critical and extremely effective to address the prevalent limitations related to resource miss utilization and misallocation, bad performance, and other corrections related to administration and miss-implementations. But now a day's this traditional evaluation (gimgema) is there only to pretend as if there is evaluation but is extremely lose and is for the sake of formalities followed by unexpected repercussions, their (informant) expression goes as follows:

"based on the experiences we have from the weyane system" ${ }^{12}$ and believing that evaluation will bring change we often evaluate and discuss any problems, evaluating the concerned officials but it had hardly any effect on correcting previous pit falls; it remains heard but not implemented. In return, either the person who evaluated or the relatives might face the cost (harassed, marginalized from all necessary benefits and tortured). All such acts made us to not evaluate the incumbents(Informants view; 2009, and August, 2011).

Following the above analysis further check were made disaggregating respondents based on their responsibilities (administrators and normal citizens), their dis/satisfaction was evaluated

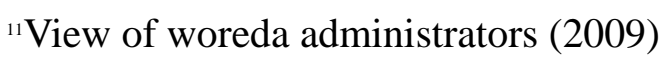

${ }^{12} \mathrm{~A}$ system of the Tigrian People Libration Front, one of the current political parties (EPRDF government) who informally administered the rural Tigray from1974 to 1991. The late administration was highly appreciated by the local people in all the woredas. 
based on the answers given to the stated indicators and are given in table ${ }_{5}$. The number are the total counts used to identify the variations in between these two groups (first and second group).

Table 5. Summery result of the descriptive statistics related to governance disaggregating respondents.

\begin{tabular}{l|l|l|l|l|l|l|l|l}
\hline & \multicolumn{4}{|l|}{ Response from Administrators } & \multicolumn{2}{l}{ Response from Community } \\
\hline No & Variable & Before & After & Difference & Variable & Before & After & Difference \\
\hline 1 & Very good & 26 & 120 & 94 & Very good & 19.6 & 25 & 181.9 \\
\hline 2 & Good & 138 & 364 & 226 & Good & 153.1 & 181.9 & 318 \\
\hline 3 & Average & 470.5 & 258 & -211 & Average & 145.5 & 413.8 & 115.2 \\
\hline 4 & Poor before & 476 & 141 & 335 & Poor & 636 & 465.4 & -171 \\
\hline
\end{tabular}

Sources: own computed

The change was observed based on the level of satisfaction of the respondents in after than before ; computed by the number of votes for all the question of indicators (question 1 up to 7 stated above) of governance. The procedure used was estimating the number of counts or scores for all responses ( $\mathrm{v}$ good, good, average and poor) by each category (community and administrator). After the counts a comparison was made, estimating the rate of changes (percentage of gains after) which also shows the level of satisfaction by these two categories. This enabled us to see the effect of decentralization on governance using similar approach as applied above. Based on the result given (Table5) we observed change but considering the responses of the communities we have noticed that their dissatisfaction outweighs. Administrators' response of having highest score differences of very good and good and lowest score differences of average and poor in after. But statistical results of communities' responses show highest score of average followed by poor. This indicates that the governance reform agenda could be strong, but its success will largely depend on the adequacy of implementation capacity, political commitment, and incentives of the different actors. Despite the general logic that both categories acknowledge the challenges of DLDP their perception related to its intensity is not the same. Administrators' response seems their satisfied about decentralization effect on governance outcome is obvious, which could be effect of different reason. First, the act of miss use or miss allocation of resource tends to be either by all or part, which make them gainers of the process, or not able to recognize its actual effect as they are the owners of the process implementation, and/or pretending about its effect feeling the consequences.

Findings presented in Table 5 confirmes the achievements of decentralization on governance; but perceptions from interviewed individual's still differ considerably. To examine the variations among respondents and in between the study woredas, we applied multivariate analysis of variance (MANOVA) and results have been discussed below (table6). 
Table 6. MANOVA Statistical Result of Good Governance

\begin{tabular}{|c|c|c|c|c|c|c|}
\hline \multirow{2}{*}{\multicolumn{2}{|c|}{ Source/ Statistic }} & $=$ place & \multicolumn{2}{|c|}{$\begin{array}{l}\text { Number of observations: } 191 \\
\mathrm{~W}=\text { Wilks' lambda } \\
\mathrm{P}=\text { Pillai's trace }\end{array}$} & \multicolumn{2}{|c|}{$\begin{array}{c}\mathrm{L}=\text { Lawley-Hotelling trace } \\
\mathrm{R}=\text { Roy's largest root }\end{array}$} \\
\hline & & df & df & df1, & $\mathrm{F}$ & \\
\hline Source & Statistic & df & $\mathrm{F}(\mathrm{df} 1$ & df 2 & $\mathrm{~F}$ & Prob $>F$ \\
\hline \multirow[t]{4}{*}{ model } & $\begin{array}{ll}\text { W } & 0.8097 \\
\end{array}$ & 4 & 8.0 & 370.6 & 5.15 & $0.0000 \mathrm{e}$ \\
\hline & $\begin{array}{ll}\mathrm{P} & 0.1944 \\
\end{array}$ & 8 & 372.0 & 5.01 & & $0.0000 \mathrm{a}$ \\
\hline & $\begin{array}{ll}\mathrm{L} & 0.2300 \\
\end{array}$ & 8 & 368.0 & 5.29 & & $0.0000 \mathrm{a}$ \\
\hline & $\begin{array}{ll}\mathrm{R} & 0.2054 \\
\end{array}$ & 4 & 186.0 & 9.55 & & $0.0000 \mathrm{u}$ \\
\hline Residuals & \multicolumn{6}{|c|}{186} \\
\hline \multirow[t]{4}{*}{ Code } & $\begin{array}{ll}\mathrm{W} & 0.9197 \\
\end{array}$ & 1 & 2.0 & 185.0 & 13.59 & $0.0000 \mathrm{e}$ \\
\hline & $\mathrm{P} \quad 0.0807$ & & 2.0 & 185.0 & 13.59 & $0.0000 \mathrm{e}$ \\
\hline & L $\quad 0.1469$ & & 2.0 & 185.0 & 13.59 & $0.0000 \mathrm{e}$ \\
\hline & $\begin{array}{ll}\mathrm{R} & 0.1469 \\
\end{array}$ & & 2.0 & 185.0 & 13.59 & $0.0000 \mathrm{e}$ \\
\hline \multirow[t]{4}{*}{ Place } & $\begin{array}{ll}\mathrm{W} & 0.9197 \\
\end{array}$ & 3 & 6.0 & 370.04 & 2.63 & $0.0163 \mathrm{e}$ \\
\hline & $\begin{array}{ll}\mathrm{P} & 0.0807 \\
\end{array}$ & & 6.0 & 372.0 & 2.61 & $0.0173 \mathrm{a}$ \\
\hline & L $\quad 0.0868$ & & 6.0 & 368.0 & 2.66 & $0.0154 \mathrm{a}$ \\
\hline & R $\quad 0.0807$ & & 3.0 & 186.0 & 5.01 & $0.0023 \mathrm{u}$ \\
\hline Residual & \multicolumn{6}{|c|}{186} \\
\hline Total & \multicolumn{6}{|c|}{190} \\
\hline
\end{tabular}

Source own computed using Stata

The letter given refers to, $\mathrm{e}=$ exact, $\mathrm{a}=$ approximate, $\mathrm{u}=$ upper bound on $\mathrm{F}$

Unfortunately, the MANOVA used to examine decentralization effect on governance could not generate answer for the interaction variable, code\#place. Result reveals all four multivariate tests reject the null hypothesis, indicating some kind of difference between the four-dimensional mean vectors of the model given by the level of 'Landa 'value, Wilks' lambda, which is exactly significant for both independent variables.

This explains how the communities' perception is different from these of administrators and at the same time views obtained from each wereda respondents regarding governance is not identical. Related to code, Landa variance might have been caused because of the differences in perception, which was noticed by the views forwarded by communities and administrators that are completely different and are having different level of satisfaction.

In our study issues pertained to governance tends to be better in the woredas that are with less resource than in the other, no resource followed by no miss-use or miss-allocate. This finding is the same as Nupia (2006) and Juan C. (2001). Both, these studies showed how the existence of relative poor and rich with a weak accountability sector in developing countries is a factor that affected decentralization to don't work appropriately. Even in the four study woredas 13 there is progresses but advancement is said to be mixed with regard to citizens' empowerment and the strengthening of local governance as indicated by the MANOVA result above table.

${ }^{13}$ Atsebi, Wekero, Hagereselam, and Tankaabergele 


\subsection{Region to Woreda Resource Transfer: Local Revenue and Expenditure Mixes July 14}

District Level of Decentralization Program was expected to improve the resource allocation practices in the small administrative region (woreda), and improving of locals' participation in development. It was an institutional system introduced to narrow the vertical and horizontal imbalances. This is supposed to be reflected by the increasing of revenue of each woreda, (collected in the form of tax). Consequently, peripheries (small administrative units) were expected to increase their efficiency, productivity, and wellbeing as a result of increasing resources. This study tired to look at the revenue and expenditure mixes of the study woredas, sort of assessing how decentralization helped to rise revenue after fiscal decentralization (DLDP) launched presuming the above analogy would practically occurred

The concept of 'periphery' in this paper denotes 'space', used to discuss about woreda development budget, which represents the core element of local government financial management system. Because there is a direct relationship between revenue and development, woredas can implement more development programs provided if they have resources (revenue). Local government plan, implement, and evaluate local development policies through the budget (Gianakis and McCue, 1999). It is the principal instrument by which government translates into action the policies and programs set out in its development plans, and it plays a pivotal role in the financial management of the economy (Melesse, 2003). This underlines the necessity of public sector intervention to attain fair distribution of resources (distribution function), and maintaining stable prices (stabilization). This is an ideology in line with the conventional literature of fiscal federalism conceded by Richard Musgrave (1959).

If a nation is following decentralization system in the process of achieving development, sub national governments are expected to play a dominant role as they are expected to have access to better information about the local circumstances. In Ethiopia, regions transfer subsidies to peripheries to enable the latter to effectively undertake their development activities properly, which are mainly done on the basis of formula (which is already revised now) similar to the core principle of the federal government. This formula constitutes population (55\%), development level (30\%), and own revenue $(15 \%)$. The budget allocations follow both budget formula and expenditure and are used to implement the instrument of block grant. Nevertheless there are also other transfers from region to woredas which are not part of the grant transfer system. These includes consolidate budget adjustment, contingency assistance, training support, selected cash transfer for capital and operating purposes, food security and food aid, asset transfer, etc. This describes how the budget formula is too fragmented and less responsive to reduction of inequality. The access and opportunities existed in that area could also be a fact for economic gaps to prevail, some woredas might have the opportunity of having high budget than the other, which comes straight as budget support made by NGOs.

Revenue source of small administrative is from both, external (obtained from the federal, or donors), and internal (income collected in the form of tax). Resources obtained in both forms varies from place to place and is related to the links with donors and each woreda's 
agriculture or other economic activities, which includes income tax, business tax, rental tax, sales tax, agricultural land use charges, and rural land utilization charges. However, considering the internal resource in the study woredas agricultural tax is the main source of internal revenue, which contributes close to $80 \%$ of the rural woreda revenue. From what is discussed the researchers noticed that in either of the cases (using internal, or external) decentralization is not offsetting inequalities between rich and poor areas. The only difference noticed was local authorities in rich weredas and with better facilities (like wekero/Keleteawelelo) has the competitive advantage, and can mobilize substantial resources to attract relatively qualified labor and to deliver high quality and efficient services compared to poor weredas (like Tankuabergele). The other factors which disallowed decentralization to work appropriately in developing countries in general and in the study woredas in particular is the existence of relative poor and rich regions with a weak accountability sector, and the high between jurisdiction income inequality, which intensify the use of transfers in order to finance the poorest regions (Oskar, 2006). Moreover, the existed opportunities; access to services, and skilled manpower also contributes to the increasing of development variations among these woredas.

Because of all these there are horizontal imbalances; all the study woredas are neither in the state of rising high revenue nor the prevalent condition to let them to do so, which led to the huge gap between revenue and spending. Moreover, the existed opportunities; access to services and skilled manpower also contributes to the increasing of development variations among these woredas. Similar to other countries experiences, small administrative units have very little room to maneuver in terms of the link between sources of revenue and expenditure allocations B. Elhiraika (2007). This is one of the reasons for the poor woredas to be less responsive and less accountable to the preferences of the local people. For instance of the study woredas compared to kileteawelaelo in Tankuabergele, administrators were complaining about resource shortage (both, revenue collected and budget received from region ) and communities were also less satisfied.

This implies all the study woredas don't have equal access and potential, which accounts for the relative differences in resource availability and implementation capacity. Even though all the four study woredas were complaining about budget these who are far from the main road, like Tankaabergle felt worse. This Peri-urban woreda (like Kilteawelaelo) is better off in rising revenue, and at the same time their reliance on regional subsidy is lesser than the remote woredas (Tankuaabergele). In line with this, the woreda officials (key informants) of Tankuaabergele showed reservations about their woreda's performance and their reason for lower revenue, their main justification hinges on the potential of the woreda to attract donors/investors and budget formula.

One of the main concern the researchers noticed was the budget formula which are used as a means of equalization program and its allocation are no longer tied to fiscal disparities among provinces. Even the woredas are not contented with the current resource allocation system because the resource transfer system is extremely fragmented and might affect the performance of woredas. This pinpoints on the limitation of having a system that combines the non-block grants to the block grant so as to increase accountability, efficient utilization of 
public resources and reducing of horizontal imbalances. In addition, the financial capacity of the woredas is too weak and local administrators were given many responsibilities that overlap each other and are with out sufficient amount of budget. This has led to a huge gap and for better understanding see the diagram below and indicates instances of the imbalances, considering two of the study woredas (Kilteawelelo and Atsebi).

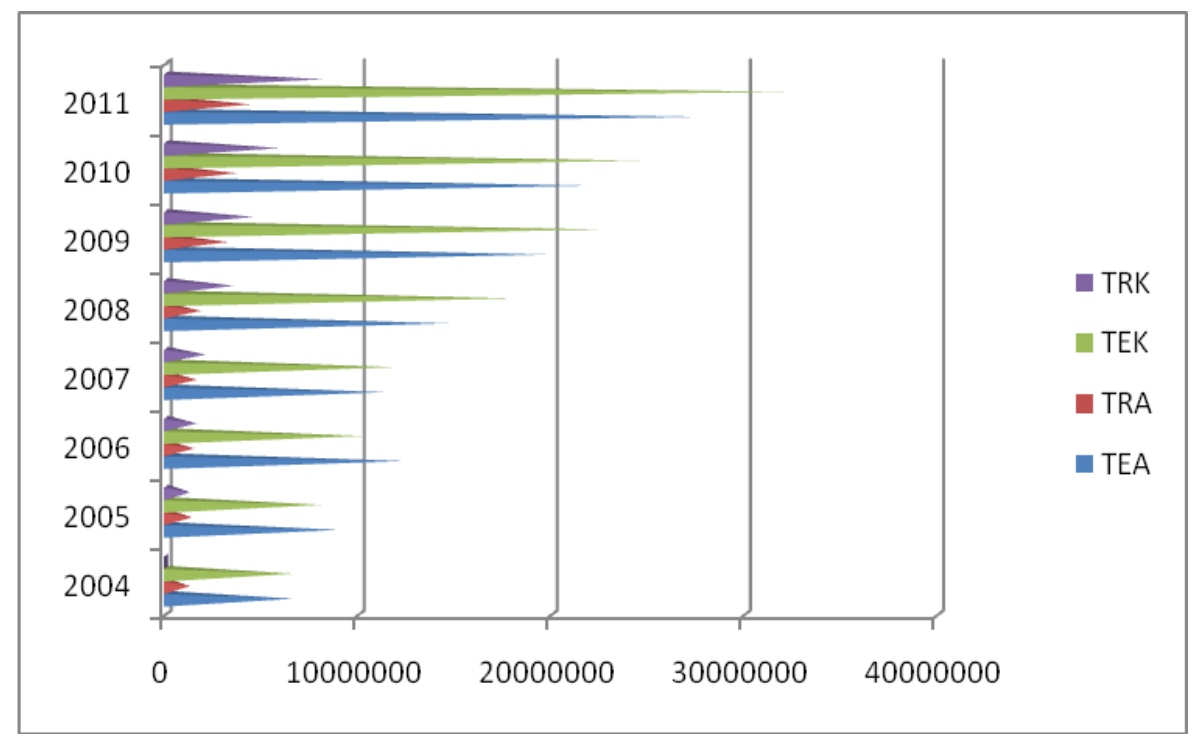

Figure 1 . TRK \& TEK refers to total revenue and total expenditure of Kelteawelaelo, TRA \& TEA refers to total revenue and total expenditure of Atsebi.

The above figure (Fig1) used to explain the instance of revenue expenditure gap of some of the study woredas. It was limited only to these two because in other of the study woredas there is no enough data. The gap in between these two woredas still indicates the horizontal imbalances, which could also be used as an example why woreda inequality to remain visible.

This is similar to the views given by the woreda official about the resource availability, and resource gap, and verifies how horizontal imbalance is affecting woredas performances. In both woredas the total expenditure is higher than the total amount of revenue collected, and the gap is very large. Apparently, decentralization managed to increase community participation in development, and community communication for development. However, its effects on maintaining of equality (reducing difference in between the woredas), its response in narrowing horizontal imbalances is still far behind. As a result, it is not surprising that DLDP, the equalization program (budget formula) has been subject to constant criticism and demands for change over the years. Fiscal disparities between the provinces will widen, placing even greater pressures on their ability to deliver adequate public services. This effect of poor technical capacity, led to the increasing of dependantistas, which hindered woredas to don't be independent decision makers, woreda pushes sub-national governments to seek more subsidy and grants from the central government (Meheret, 2007). These institutional shortcomings, in turn, hindered the effectiveness and responsiveness of the state in public service delivery. In spite of the appreciation of their newly gained autonomy, there is a 
general recognition that woredas still depend (e.g. personnel deployment, guidelines, training, etc) much on the region. In addition we have noticed the lose cooperation between region and woredas. Neither Woredas have the required skill to design, plan, and implementation and nor region did have strong supervision that can help to solve the technical (skill) related problem of these woredas. Issues pertinent to region supervision to the small woredas are becoming worse after introduction of fiscal decentralization than before. All study woredas appreciated the technical support they had from the region in pre-fiscal decentralization period and are still demanding to resume these supports even now. Otherwise these paucities are hindering woredas not to realize their development objectives, which in turn may still affect their socio-economic performances.

\section{Conclusion and Recommendation}

This study focused on examine the impacts of decentralization on rural development considering some of the rural woredas of Tigrai; Kaelteawelaelo, Atsebi, Hageresealm, and Tankuabergele.

In the rural part of Tigrai decentralization was launched in the 1980s, during the Derg era. By then, the rural areas were not fully governed by the Derg system. The EPRDF, then called guerrilla fighters, who had asserted full power on the people on matters of political and administrative decisions albeit their system was not institutionalized (informal) but had governed all rural areas and some small towns. This helped when the current government (EPRDF) became a ruling party of the Ethiopian state to echo on decentralization and advantage of introducing a system gives power to the people and encourages people participation in development. Due to this the Ethiopian government launched various economic reform programs since $1992 / 93$ and decentralization is one of them. Decentralization was expected to bring about tremendous changes that contribute to the growth of the economy by transforming the institutional system, and was expected to enhance individuals' participation in economic, political and social affairs, and improving of the governance system.

This study was conducted to see the effect of this system. Findings shows decentralization led to improvements in participation, and governance, which in turn led to increasing of economic efficiency. However, its relative effects are higher in terms of enhancing public participation than improving governance, narrowing revenue expenditure gaps, and horizontal imbalances. In addition this study found that effect of fiscal decentralization to be higher in improving locals participation on political and development matters than on governance.

When decentralization is evaluated on the basis of resource (budget) obtained, it is possible to say that the essence of centralization still exists. Because Tegray region gets its main resource (revenue) block grant and subsidy form the federal state and in turn the region also extends the same resources to the weredas in the real spirit of decentralization. This indicates that since all development activities of small administrative units is depending on the resource they obtain then their full independent remains questionable. Of all the remarkable changes researchers observed how woreda participation in implementing of regional planning and 
community based development activities, their mandate of coordinating community based development activities (CBO)) and in deciding community contributions to development became better after decentralization.

However, many stakeholders, especially woreda officials and elected representatives feel that more support is needed (including repeated short and long term training). They deem that lack of skill and technical application is making them to be less responsive to the calls (development related) made by the region. This view is similar to Poverty Participatory Assessment 2005 (MOFED 2005 (a)).

Another important issue noticed was the trade off in the implementation of institutional system, differences between decentralization and Business Process Reengineering (BPR). BPR is a system that involves the head (leader) works in a team and has to pull his type (teaming) but the community might not be in favor of that person. This contradicts with the principle of decentralization, it is always difficult to coordinate team making, and respecting individuals' choices. When the community have different choice than that person it may led to unexpected results that affect the institutional stability and other developments. Related to this most informants said when BPR came as a tool to some extent the political decentralization is violated because BPR is team making that implies we are not administered by the person whom we chosen.

Decentralization never offset the problem of unfair Resource (budget) transfer and allocation, and is one of the core emphasis in all woredas studied. This reveals decentralization never offset the problem of resource allocation and inequality in between the small administrative regions. For instance, the better woredas like the better Regions (Eg: Southern Region), which has locational advantage have an opportunity in attracting more donors which led to better budget endowments than the others. Therefore, the structural imbalances in geographic, material, socio-economic and natural situation of the woredas has to be balanced by making certain adjustments in such a way that solves inequalities.

Finally, the issue of governance requires major change and wider attention. This can come up as a result of appointing accountable individuals and creating concerned citizens thorough time. But strong supervision by the regions, and conducting of quarterly, or semiannual monitoring and evaluation would also help to understand and know the nature and character of the administrators in the small administrative unit that make easier to take corrections.

Over all, even though the achievements made so far are quite encouraging, the fruits of decentralization are yet to be reaped overcoming some of the current limitations singled out in each study woreda, which included miss implementation of institutional laws, shortage of resource (budget), poor technical capacity and information asymmetry, and clarity about the decentralization. From the discussion and reviews we have noticed that this institutional system and its essence is sometimes miss interpreted and miss understood, practically its effect on the administration is more of centralization despite the name decentralization exists. 


\section{References}

Abay, A., Frohberg, K., James, K. S., \& Jütting, J. (2004). Modeling the Impact of Fiscal Decentralization on Health Outcomes: Empirical Evidence from India. ZEF Discussion Papers on Development Policy, Bonn.

African Development Bank, and African Development Fund. (2009). Federal Democratic Republic of Ethiopia Country Governance Profile, Report.

Bardhan, P., \& Udry, C. (1999). Development Microeconomics, Oxford University Press. ISBN 0-19-877370-6. https://doi.org/10.1093/0198773714.001.0001

BoFED. (2006). Bureau of finance and economic development. GIS department. Mekelle (unpublished).

Bureau of Planning and Economic development. (1995). Five Year Development Plan of the Tigray Region. Mekelle, Ethiopia (Draft compiled by the Region).

Chatfield, C. (1995). Model Uncertainty, Data Mining and Statistical Inference. JRSS-A 158, 419-466. https://doi.org/10.2307/2983440

Dethier, J. (ed.) (2000). Governance, Decentralization and Reform in China, India and Russia. Kluwer Academic Publishers and ZEF.

DLDP Review, PPA, CIDA cited in Dom and Mussa. (2006). Review of Implementation of the Decentralization Policy: A Sample Survey in Four Sentinel Woredas of Tigray Region.

Dom, C., \& Mussa, M. (2006a). Review of Implementation of the Decentralization Policy: A Sample Survey in Four Sentinel Weredas of Tigray Region. Report for the Embassy of Ireland and Regional Government of Tigray. Oxford, UK.

Elhiraika, A. B. (2007). Fiscal Decentralization and Public Service Delivery in South Africa. Canada Fund for Africa.

Faraway, J. J. (2002). Practical Regression and Anova using R. Manuscript.

Getachew, M., \& Fraser, T. (2001). Decentralization and Local Autonomy: Regional planning in Ethiopia cited in a Book New Regional Development Paradigms-Volume 3, by B. Stohr, W. et al. (Ed.), Greenwood Press, London.

Hertogs, E. J. (1999). What Role for Local Authority in Decentralized Cooperation Under Convention of Lome. ECDPM Discussion Paper No. 8 cited in Tewodros, B.2005.

Juan, C. M. (2001). Analysis of Public Decentralization in Spain. Journal of Public Finance and Management, 1(4), 500-556.

Khaleghian, P. (2003). Decentralization and Public Services: The Case of Immunization. World Bank Policy Research Working Paper, No. 2989, World Bank, Washington, D.C. https://doi.org/10.1596/1813-9450-2989 


\section{Macrothink}

Journal of Public Administration and Governance ISSN 2161-7104 2018, Vol. 8, No. 2

Local Development International. (2013). The Role of Decentralization/Devolution Improving Development Outcomes at the Local Level: Review of the Literature and Selected Cases, UK Department for International Development South Asia Research Hub, Brooklyn, New York. USA.

Martinez, V. J. (2011). Impact of Fiscal Decentralization, Issues in Theory and Challenges in Practices. ADB Publication.

Meheret, A. (2007). A Rapid Assessment of Woreda Decentralization in Ethiopia'. Forum for Social Studies, Addis Ababa.

Melese, D. (2003). Urban Financial Management, Module 3 for MDP Training Program, $5^{\text {th }}$ Urban City Management Course for Africa, http;//info.worldbank.org/etools/docs/Liberary/114925/eum/docs/eum/ehiopiaeum/Module3 Urban Financial Management.

MOFED. (2005). Ethiopia Participatory Poverty Assessment 2004-05, Addis Ababa, Ethiopia. MOFED. (2010). Trends and Prospects for Meeting MDG by 2015. 2010 MDG Report, Addis Ababa, Ethiopia.

MOFED. (2012). Ethiopia's Progress Towards Eradicating Poverty: an Interim Report on Poverty Analysis Study (2010/11). Addis Ababa, Ethiopia.

Nadeem, S. B., N., Qaiser, M., \& Kamal, S. (2008). MANOVA with Summary Statistics: A STATA Program. College of Statistical and Actuarial Sciences, University of the Punjab, Lahore.

Ndegwa, S. (2002). Decentralization in Africa; A Stocktaking Survey Africa Region. Working Paper Series No.40, World Bank Washington.

Nupia, O. (2007). Decentralization, Corruption, and Political Accountability in Developing Countries, Universitat Pompeu Fabra.

Oskar, N. (2006). Decentralization, Corruption and Political Accountability in Developing Countries, Working paper.

Shah, A. (2006). Corruption and Decentralized Public Governance, World Bank Publication. https://doi.org/10.1596/1813-9450-3824

Shah, A., Thompsont., \& Zou, H. (2002). The Impact of Decentralization on Service Delivery, Corruption, Fiscal Management and Growth in Developing and Emerging Market Economies: A Synthesis of Imperial Evidence. CES ifo DICE Report.

Smith, S. C. (2005). Ending Global Poverty. Palgrave Macmillan, New York.

Spielman, D. J., Cohen, M. J., \& Tewodaj, M. (2006). Mobilizing Rural Institutions for Sustainable Livelihoods and Equitable Development: A Case Study of Local Governance And Smallholder Cooperatives in Ethiopia, IFPRI, Addis Ababa, Ethiopia, working paper. 
Steinich, M. (2002). Monitoring and Evaluating Support to Decentralization, Challenges and Dilemmas. A Seminar Paper on - European Support for Democratic Decentralization and Municipal Development- A Contribution to Local Development and Poverty Reeducation, - held in Maastricht, 14-15 organized by ECDPM and Swedish Ministry of Foreign Affairs.

Stöhr, W. B., Edralin, J. S., \& Mani, D. (eds.) (2001). New Regional Development Paradigms. Vol. 3, Greenwood Press, London, pp. 21-35.

Tanzi, V. (1995). Fiscal Federalism and Decentralization: A Review of Some Efficiency and Macro Economic Aspects', in Bruno, M. and Pleskovic, B. (eds.): Annual World Bank Conference on Development Economics, Washington D.C, World Bank.

Tegenge, G., \& Kassahun, B. (2007). The Role of Decentralization Governance in Building Local Institutions, Diffusing Ethnic Conflicts, and Alleviating Poverty in Ethiopia. Regional Development Dialogue, 25(1).

Tesfay, T. (2006). Decentralization and Service Delivery in Ethiopia; (A Case of Moretenna-Girr and Bereh Aletu Woredas in Amhara and Oromia Regions Respectively). MA Thesis, RLDs/AAU, Addis Ababa.

Tewdros, B. (2005). Decentralization Development Cooperation, Governance and Rural Livelihood: The case of Amhara region. Ethiopia in Issues and Challenges in Local and Regional Development, Tegegne g., and Pitter Van Dijk, P. 2005 (Edi.).

Turner, M., \& David, H. (1997). Governance, Administration and Development; Making the State Work, New York, Palgrave. https://doi.org/10.1007/978-1-349-25675-4

UNCDF. (2003). Decentralization and Local Governance From the Perspective of Poverty Reduction. Human Rights, Humanitarian Aid and Peace Building Department, Good Governance and Peace Building Division (DMV/VG).

World Bank. (2003). Making Services Work for Poor People. World Bank and Oxford University Press, Washington, D.C.

Yigremew, A., Nega, W., \& Haregewoin, C. (2005), study on implementation of Decentralization Policy in Ethiopia Oxfam GB Ethiopia Publications.

Yon, B. J., \& Grote, U. (2001). Does Decentralization Serve the Poor? In: IMF, Fiscal. Chatfield, C. (1995). Model Uncertainty, Data Mining and Statistical Inference. JRSS-A 158, 419-466.

\section{Copyright Disclaimer}

Copyright for this article is retained by the author(s), with first publication rights granted to the journal.

This is an open-access article distributed under the terms and conditions of the Creative Commons Attribution license (http://creativecommons.org/licenses/by/4.0/). 